\section{Identification of Climacteric and Nonclimacteric Phenotypes of Asian Pear Cultivars by CAPS Analysis of 1-Aminocyclopropane-1-Carboxylate Synthase Genes}

\author{
Akihiro Itai ${ }^{1}$ and Naoko Fujita \\ Laboratory of Horticultural Biotechnology, Faculty of Agriculture, Tottori \\ University, Tottori 680-8553
}

Additional index words. Asian pears, storage potential, CAPS, ethylene synthesis, marker assisted selection

\begin{abstract}
The maximum level of ethylene production is closely related to fruit ripening and storage potential in Asian pears. In a previous study, we identified two markers (A and B) linked to high and moderate ethylene production during fruit ripening, respectively, by restriction fragment-length polymorphism analysis of two 1-aminocyclopropane-1-carboxylate (ACC) synthase genes (PPACS1 and PPACS2). In this study, a total of 152 cultivars were categorized into four marker types $(A B, A b, a B$, and $a b)$; types $A B$ and $A b$ show high levels, $a B$ a moderate level, and ab a low level of ethylene production during fruit ripening. A large number of ab and $a B$ cultivars but few $A B$ and Ab cultivars were observed. It suggests that there has been a decrease in high ethylene producers by artificial selection because of short shelf life. The ab cultivars are a good genetic resource for production of new cultivars with a long shelf life. Such information on marker types is useful for breeding strategies aimed at improving storage ability in Asian pears.
\end{abstract}

In Pyrus, there are three major species, P. communis L. (pear or European pear), $P$. bretschneideri Rehd. or P. uusuriensis Maxim. (Chinese pear), and $P$. pyrifolia Nakai (Japanese pear: Nashi), which are commercially cultivated in temperate zones. The attributes that constitute good quality in one species may differ from that in another, as is the case with European and Asian pears. The attributes of European pears, for example, include its soft buttery texture, whereas those of Asian pears include its juicy and crisp flesh. The most distinctive characteristic of Asian pears is the fact that they mature on the tree in contrast to European pears, which usually require exposure to chilling temperatures for initiation of ripening.

Pear fruits can be classified as climacteric or nonclimacteric according to their ripening characteristics. European pears are climacteric (Jackson, 2003), whereas Asian pears are thought to include climacteric and nonclimacteric cultivars because climacteric type fruits showed a rise in respiration and

\footnotetext{
Received for publication 14 June 2007. Accepted for publication 7 Sept. 2007.

This study was partially supported by Grants-in-Aid (Nos. 17380023 and 18780021) from the Ministry of Education, Science, Sports and Culture, Japan, and by a grant from the Venture Business Laboratory (VBL) of Tottori University, Japan.

${ }^{1}$ To whom reprint requests should be addressed; e-mail itai@muses.tottori-u.ac.jp
}

ethylene production, and nonclimacterictype fruit did not show a rise in respiration and ethylene production during fruit ripening (Downs et al., 1991; Itai et al., 1999, 2003a; Kitamura et al., 1981). In Asian pears, climacteric-type fruits have a low storage potential, whereas nonclimacteric fruits maintain fruit quality for over 1 month in storage (Itai et al., 1999, 2003a; Kitamura et al., 1981). Therefore, fruit storage potential is closely related to the maximum level of ethylene production in Asian pears.

We previously cloned three 1-aminocyclopropane-1-carboxylate (ACC) synthase genes (PPACS1, 2, and 3) and studied their expression during fruit ripening (Itai et al., 1999, 2003b). PPACS1 was specifically expressed in cultivars showing high ethylene production $\left(>10 \mathrm{~nL} \cdot \mathrm{g}^{-1} \cdot \mathrm{h}^{-1}\right.$, usually over $\left.50 \mathrm{~nL} \cdot \mathrm{g}^{-1} \cdot \mathrm{h}^{-1}\right)$, and PPACS2 in cultivars showing moderate ethylene production $\left(0.5 \mathrm{~nL} \cdot \mathrm{g}^{-1} \cdot \mathrm{h}^{-1}\right.$ to $\left.10 \mathrm{~nL} \cdot \mathrm{g}^{-1} \cdot \mathrm{h}^{-1}\right)$. Moreover, we previously identified restriction fragmentlength polymorphism (RFLP) markers linked to the ethylene production in ripening fruit using RFLP analysis with two ACC synthase genes (PPACS1 and PPACS2) (Itai et al., 1999). These RFLPs were designated A ( 2.8 $\mathrm{kb}$ of $P P A C S 1)$, which is linked to high levels of ethylene, and $\mathrm{B}(0.8 \mathrm{~kb}$ of $P P A C S 2)$, which is linked to moderate levels. Based on this analysis, we classified 35 Asian pear cultivars into four RFLP types (AB, $\mathrm{Ab}, \mathrm{aB}$, and $\mathrm{ab}$ ), of $\mathrm{aB}$ a moderate level, and $\mathrm{ab}$ a low level of which types $A B$ and $A b$ show high levels, ethylene production during fruit ripening (Itai et al., 1999). We further transformed these two RFLP markers into more convenient easy-to-use polymerase chain reaction (PCR)-based CAPS markers (A: $1.57 \mathrm{~kb}$ and $0.63 \mathrm{~kb}$ of the PPACS1 fragment; $\mathrm{B}$, $0.83 \mathrm{~kb}$ and $0.35 \mathrm{~kb}$ of PPACS2 fragment) (Itai et al., 2003b).

These markers are useful for predicting the ethylene levels of Asian pear cultivars and they enable identification of low ethylene producers with an enhanced postharvest storage ability. However, available information on ethylene production is limited to certain cultivars. Therefore, in the present study, we conducted CAPS analysis of 152 cultivars using two ACC synthase genes to evaluate the ripening characteristics and to improve breeding and posthandling information on Asian pears.

\section{Materials and Methods}

Plant materials. A total of 152 Asian pear cultivars including 35 previously identified cultivars were investigated. All cultivars were grown at the orchard of Tottori University, Japan. Young leaf samples were obtained from one tree per cultivar and were stored at $-80{ }^{\circ} \mathrm{C}$ until DNA extraction.

$D N A$ extraction. The DNA extraction protocol was a modified version of the sodium dodecyl sulfate (SDS) method published in Dellaporta et al. (1983) with some additional washing steps (Itai et al., 2003a). About $100 \mathrm{mg}$ of leaf material was ground in liquid nitrogen using a mortar and pestle and the powder was then transferred to a $1.5-\mathrm{mL}$ tube containing $1 \mathrm{~mL}$ of washing buffer [0.1 M Hepes, $\mathrm{pH} 8.0,0.1 \%$ polyvinylpyrolidone $(\mathrm{K}-30)$, and 2\% 2-mercaptethanol]. The mixed solution was centrifuged at $15,000 g_{a}$ for $10 \mathrm{~min}$ and the supernatant was then discarded and the pellet was resuspended in $1 \mathrm{~mL}$ of the same washing buffer. This washing step was repeated three times to remove polysaccharides and polyphenols. After washing, the pellet was resuspended in $400 \mu \mathrm{L}$ of extraction buffer $(0.5 \mathrm{M} \mathrm{NaCl}$, 100 mm Tris-HCI, pH 8.0, 50 mм EDTA-Na, and $2 \%$ SDS) and was incubated at $70{ }^{\circ} \mathrm{C}$ for $10 \mathrm{~min}$. After incubation, $120 \mu \mathrm{L}$ of $5 \mathrm{M}$ potassium acetate was added to the mixture and centrifuged at $15,000 g_{\mathrm{a}}$ for $15 \mathrm{~min}$. The supernatant was transferred to a new tube to which an equal volume of 2-propanol was added and the DNA was then precipitated and recentrifuged. The precipitated DNA was dissolved in $20 \mu \mathrm{L}$ of Tris-EDTA with $1 \mu \mathrm{L}$ of RNase A $\left(10 \mathrm{mg} \mathrm{mL}^{-1}\right)$, incubated at $37^{\circ} \mathrm{C}$ for $30 \mathrm{~min}$, and then stored at $4{ }^{\circ} \mathrm{C}$.

$P C R$ reaction and CAPS analysis. Forward (SYN1PU1: 5'-GATGAAATAAAGT CCACAATCAAG- ${ }^{\prime}$ ) and reverse (SYN1PD1: 5'-GCGTTTCTGC.ATAACATGCG-3') primers were used for classification of marker A of PPACS1, which is linked to high ethylene production in Asian pears (Itai et al., $2003 \mathrm{~b})$. The amplification reaction was performed in $50 \mathrm{~g} \mu \mathrm{L}$ of reaction mixture containing $100 \mathrm{ng}$ of genomic DNA, $1 \times$ Taq 
polymerase buffer, 50 pmol of each primer, $0.2 \mathrm{~mm}$ each of the four dNTPs, and $1.25 \mathrm{U}$ Taq polymerase (Nippon Gene, Toyama, Japan). Amplification was carried out in a TP-2000 thermal cycler (Takara Shuzo, Kyoto, Japan) programmed for 35 cycles of $60 \mathrm{~s}$ at $94{ }^{\circ} \mathrm{C}, 60 \mathrm{~s}$ at $60^{\circ} \mathrm{C}$, and $120 \mathrm{~s}$ at $72{ }^{\circ} \mathrm{C}$, with a final cycle at $72^{\circ} \mathrm{C}$ for $10 \mathrm{~min}$. Amplified fragments were digested with HindIII for at least $3 \mathrm{~h}$ at $37^{\circ} \mathrm{C}$ and were then analyzed on a $1.2 \%$ agarose gel in $1 \times$ TAE buffer and stained with ethidium bromide. Identification of marker A was analyzed by the presence (Fig. 1) or absence of

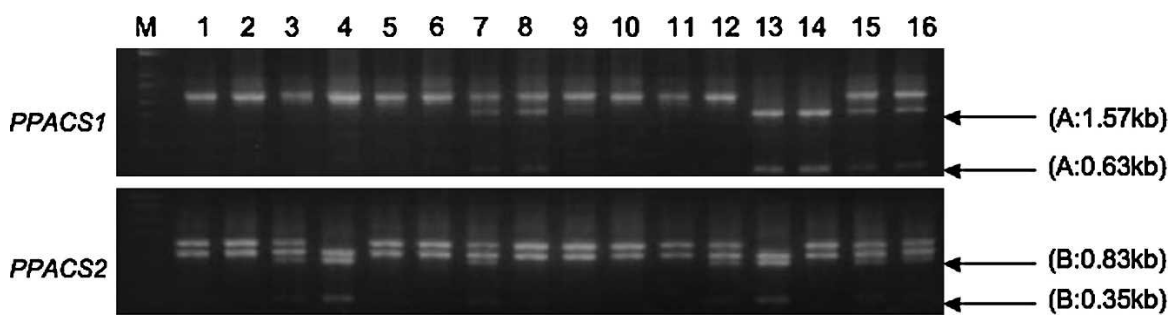

Fig. 1. CAPS analysis of the PPACS1 and PPACS2 genes in cultivars of Asian pear. Bands indicated by arrows, $\mathrm{A}$ and $\mathrm{B}$, are specific to cultivars that produce high and moderate levels of ethylene during fruit ripening, respectively. $\mathrm{M}=$ molecular marker; $1=$ Koyuki; $2=$ Ruisannashi; $3=$ Jianbali; $4=$ Asahi; 5 = Aoyagi; 6 = Kousainashi; 7 = Pingli; $8=$ Baili; $9=$ Hattatsu; $10=$ Echigonishiki; $11=$ Kuninaga; $12=$ Kiyosumi; $13=$ Qiubaili; $14=$ Huangli; $15=$ Shuixiangli; $16=$ Kogetsu .

Table 1. Marker types representative of ethylene synthesis during fruit ripening in Asian pear cultivars.

\begin{tabular}{|c|c|c|c|c|c|}
\hline$\overline{\text { Cultivar }}$ & Marker type & Cultivar & Marker type & Cultivar & $\overline{\text { Marker type }}$ \\
\hline$\overline{\text { Aikansui( }(\mathrm{P})^{\mathrm{z}}}$ & $\mathrm{aB}(\mathrm{M})^{\mathrm{y}}$ & Jinjianli(B) & $\mathrm{AB}(\mathrm{H})$ & Shinju(P) & $\mathrm{aB}(\mathrm{M})$ \\
\hline Akaho(P) & $\mathrm{aB}(\mathrm{M})$ & Kamenashi(P) & $\mathrm{Ab}(\mathrm{H})$ & Shinko(P) & $\mathrm{ab}(\mathrm{L})$ \\
\hline $\operatorname{Akemizu}(\mathrm{P})$ & $\mathrm{aB}(\mathrm{M})$ & Kansaiasahiryu(P) & $\mathrm{Ab}(\mathrm{H})$ & Shinseiki(P) & $\mathrm{aB}(\mathrm{M})$ \\
\hline Akiakari(P) & $\mathrm{ab}(\mathrm{L})$ & Kansaiichi(P) & $\mathrm{Ab}(\mathrm{H})$ & Shinsetsu(P) & $a b(L)$ \\
\hline Akibae(P) & $a b(L)$ & Kikkou(P) & $\mathrm{aB}(\mathrm{M})$ & Shikishima(P) & $\mathrm{aB}(\mathrm{M})$ \\
\hline Akizuki(P) & $\mathrm{ab}(\mathrm{L})$ & Kikusui(P) & $\mathrm{aB}(\mathrm{M})$ & Shimokaburi(P) & $\mathrm{aB}(\mathrm{M})$ \\
\hline Amanogawa(P) & $a b(L)$ & Kimitsukawase(P) & $\mathrm{aB}(\mathrm{M})$ & Shinsui(P) & $\mathrm{aB}(\mathrm{M})$ \\
\hline Aokeiniitaka(P) & $\mathrm{ab}(\mathrm{L})$ & Kinchaku(P) & $\mathrm{aB}(\mathrm{M})$ & Shirayuki(P) & $\mathrm{ab}(\mathrm{L})$ \\
\hline Aokeishinko(P) & $\mathrm{ab}(\mathrm{L})$ & Kiyosumi(P) & $\mathrm{aB}(\mathrm{M})$ & Shomyouji(P) & $\mathrm{ab}(\mathrm{L})$ \\
\hline Aoyagi(P) & $\mathrm{ab}(\mathrm{L})$ & Kohnowatari(P) & $\mathrm{ab}(\mathrm{L})$ & Shugyoku(P) & $\mathrm{aB}(\mathrm{M})$ \\
\hline Asahi(P) & $\mathrm{aB}(\mathrm{M})$ & Kogiku(P) & $\mathrm{aB}(\mathrm{M})$ & Shuixiangli(B) & $\mathrm{AB}(\mathrm{H})$ \\
\hline Asahiryu(P) & $\mathrm{aB}(\mathrm{M})$ & Kogetsu(PB) & $\mathrm{AB}(\mathrm{H})$ & Shurei(P) & $\mathrm{ab}(\mathrm{L})$ \\
\hline Awayuki(P) & $\mathrm{Ab}(\mathrm{H})$ & Konpeito(P) & $\mathrm{ab}(\mathrm{L})$ & Sotoorihime(P) & $\mathrm{Ab}(\mathrm{H})$ \\
\hline Babauchaginashi(P) & $\mathrm{aB}(\mathrm{M})$ & Kousainashi(P) & $\mathrm{ab}(\mathrm{L})$ & Suisei(P) & $\mathrm{aB}(\mathrm{M})$ \\
\hline Baili(B) & $\mathrm{Ab}(\mathrm{H})$ & Koyuki(P) & $\mathrm{ab}(\mathrm{L})$ & Taihaku(P) & $\mathrm{aB}(\mathrm{M})$ \\
\hline Balixiang(B) & $\mathrm{aB}(\mathrm{M})$ & Kozo(P) & $\mathrm{aB}(\mathrm{M})$ & Taihei(P) & $\mathrm{ab}(\mathrm{L})$ \\
\hline Beijingbaili(B) & $\mathrm{Ab}(\mathrm{H})$ & Kumoi(P) & $\mathrm{aB}(\mathrm{M})$ & Tanponashi(P) & $\mathrm{aB}(\mathrm{M})$ \\
\hline Cheongdangroli(B) & $\mathrm{ab}(\mathrm{L})$ & Kuninaga(P) & $\mathrm{ab}(\mathrm{L})$ & Tenyu(P) & $\mathrm{ab}(\mathrm{L})$ \\
\hline Cheongsilli(B) & $\mathrm{AB}(\mathrm{H})$ & Kunitomi(P) & $\mathrm{ab}(\mathrm{L})$ & Tosajo(P) & $\mathrm{aB}(\mathrm{M})$ \\
\hline Choju(P) & $\mathrm{aB}(\mathrm{M})$ & Kuroki(P) & $\mathrm{aB}(\mathrm{M})$ & Tosanashi(P) & $\mathrm{aB}(\mathrm{M})$ \\
\hline Chojuro(P) & $\mathrm{aB}(\mathrm{M})$ & Makezaoli(B) & $\mathrm{Ab}(\mathrm{H})$ & Tosanishiki(P) & $\mathrm{ab}(\mathrm{L})$ \\
\hline Chosen $(\mathrm{P})$ & $\mathrm{aB}(\mathrm{M})$ & Mili(B) & $\mathrm{ab}(\mathrm{L})$ & Tsugaruao(P) & $\mathrm{ab}(\mathrm{L})$ \\
\hline Cili(B) & $\mathrm{AB}(\mathrm{H})$ & $\operatorname{Mishirazu}(\mathrm{P})$ & $\mathrm{ab}(\mathrm{L})$ & Tsukutounashi(P) & $\mathrm{ab}(\mathrm{L})$ \\
\hline Dangshansuili(B) & $\mathrm{Ab}(\mathrm{H})$ & Miyadani(P) & $\mathrm{aB}(\mathrm{M})$ & Umajiro(P) & $\mathrm{ab}(\mathrm{L})$ \\
\hline Datouhuang(P) & $\mathrm{aB}(\mathrm{M})$ & Nakaide(P) & $\mathrm{aB}(\mathrm{M})$ & Wakahikari(P) & $\mathrm{aB}(\mathrm{M})$ \\
\hline Doitsu(P) & $\mathrm{aB}(\mathrm{M})$ & Nanseichabo(P) & $\mathrm{ab}(\mathrm{L})$ & Waseaka(P) & $\mathrm{ab}(\mathrm{L})$ \\
\hline Echigonishiki(P) & $\mathrm{ab}(\mathrm{L})$ & Nekogoroshi(P) & $\mathrm{AB}(\mathrm{H})$ & Wasekozo(P) & $\mathrm{aB}(\mathrm{M})$ \\
\hline Edoya(P) & $\mathrm{Ab}(\mathrm{H})$ & Niitaka(P) & $\mathrm{ab}(\mathrm{L})$ & Wasetaicho(P) & $\mathrm{ab}(\mathrm{L})$ \\
\hline Enli(B) & $\mathrm{AB}(\mathrm{H})$ & Nijisseiki(P) & $\mathrm{ab}(\mathrm{L})$ & Whangkeumbae(P) & $\mathrm{ab}(\mathrm{L})$ \\
\hline Fukushima(P) & $\mathrm{ab}(\mathrm{L})$ & Nikkori(P) & $\mathrm{ab}(\mathrm{L})$ & Wowoli(B) & $\mathrm{AB}(\mathrm{H})$ \\
\hline Gion(P) & $\mathrm{aB}(\mathrm{M})$ & Ninomiya(P) & $\mathrm{AB}(\mathrm{H})$ & Xiangli(B) & $\mathrm{Ab}(\mathrm{H})$ \\
\hline Gold Nijisseiki(P) & $\mathrm{ab}(\mathrm{L})$ & Ninomiyahakuri(PB) & $\mathrm{AB}(\mathrm{H})$ & Xiangyali(B) & $\mathrm{Ab}(\mathrm{H})$ \\
\hline Hakataao(P) & $\mathrm{aB}(\mathrm{M})$ & Oharabeni(PC) & $\mathrm{aB}(\mathrm{M})$ & Yahatanishiki(P) & $\mathrm{ab}(\mathrm{L})$ \\
\hline $\operatorname{Hakkou}(\mathrm{P})$ & $\mathrm{ab}(\mathrm{L})$ & Ohiromaru(P) & $\mathrm{aB}(\mathrm{M})$ & Yagoemon(P) & $\mathrm{ab}(\mathrm{L})$ \\
\hline Hamheung(Kou)(B) & $\mathrm{Ab}(\mathrm{H})$ & Ohshuu(P) & $\mathrm{ab}(\mathrm{L})$ & Yaguali(B) & $\mathrm{aB}(\mathrm{M})$ \\
\hline Hamheung(Otsu)(B) & $\mathrm{ab}(\mathrm{L})$ & Ohtani(P) & $\mathrm{Ab}(\mathrm{H})$ & Yakumo(P) & $\mathrm{aB}(\mathrm{M})$ \\
\hline Hatsushimo(P) & $a b(L)$ & Okusankichi(P) & $\mathrm{ab}(\mathrm{L})$ & Yali(B) & $\mathrm{AB}(\mathrm{H})$ \\
\hline Hattatsu(PB) & $\mathrm{Ab}(\mathrm{H})$ & $\mathrm{Onba}(\mathrm{P})$ & $\mathrm{Ab}(\mathrm{H})$ & Yanaga $(\mathrm{P})$ & $\mathrm{ab}(\mathrm{L})$ \\
\hline Hayatama(P) & $\mathrm{aB}(\mathrm{M})$ & Ookoga(P) & $a b(L)$ & Yasato(P) & $\mathrm{aB}(\mathrm{M})$ \\
\hline Hebeili(B) & $\mathrm{Ab}(\mathrm{H})$ & Osanijisseiki(P) & $\mathrm{ab}(\mathrm{L})$ & Yinbaili(B) & $\mathrm{AB}(\mathrm{H})$ \\
\hline Heishi(P) & $\mathrm{ab}(\mathrm{L})$ & Pingli(B) & $\mathrm{AB}(\mathrm{H})$ & Yuanbali(B) & $\mathrm{ab}(\mathrm{L})$ \\
\hline Heiwa(P) & $\mathrm{ab}(\mathrm{L})$ & Pingguoli(B) & $\mathrm{Ab}(\mathrm{H})$ & Yokogoshi(P) & $\mathrm{ab}(\mathrm{L})$ \\
\hline Hoeryongsaibai(B) & $\mathrm{AB}(\mathrm{H})$ & Pingzili(B) & $\mathrm{Ab}(\mathrm{H})$ & Zhuzuili(B) & $\mathrm{Ab}(\mathrm{H})$ \\
\hline $\operatorname{Hokkan}(\mathrm{P})$ & $\mathrm{ab}(\mathrm{L})$ & Qiubaili(B) & $\mathrm{AB}(\mathrm{H})$ & Zuishu(P) & $\mathrm{ab}(\mathrm{L})$ \\
\hline Hongli(B) & $a b(L)$ & Rokugatsu(P) & $\mathrm{Ab}(\mathrm{H})$ & & \\
\hline Hongxiaoli(B) & $\mathrm{ab}(\mathrm{L})$ & Ruisannashi(P) & $\mathrm{ab}(\mathrm{L})$ & & \\
\hline Hosui(P) & $a b(L)$ & Sagami(P) & $\mathrm{aB}(\mathrm{M})$ & & \\
\hline Huangli(B) & $\mathrm{Ab}(\mathrm{H})$ & $\operatorname{Saizo}(\mathrm{P})$ & $\mathrm{ab}(\mathrm{L})$ & & \\
\hline Imamuraaki(P) & $\mathrm{ab}(\mathrm{L})$ & Sannashi(P) & $\mathrm{Ab}(\mathrm{H})$ & & \\
\hline Imamuranatsu(P) & $\mathrm{aB}(\mathrm{M})$ & Seiryu $(\mathrm{P})$ & $\mathrm{ab}(\mathrm{L})$ & & \\
\hline Inagi(P) & $\mathrm{aB}(\mathrm{M})$ & Sekaiichi(P) & $a b(L)$ & & \\
\hline Inugoroshi(P) & $\mathrm{aB}(\mathrm{M})$ & Senryou(P) & $\mathrm{aB}(\mathrm{M})$ & & \\
\hline Ishiiwase $(\mathrm{P})$ & $\mathrm{aB}(\mathrm{M})$ & Shihyakume(P) & $\mathrm{aB}(\mathrm{M})$ & & \\
\hline Jianbali(B) & $\mathrm{aB}(\mathrm{M})$ & Shinchu(P) & $\mathrm{aB}(\mathrm{M})$ & & \\
\hline
\end{tabular}

${ }^{{ }^{2} I n}$ the "Cultivar" column, letters in parentheses represent the species. $\mathrm{B}=$ P. bretschneideri or $P$. ussuriensis; $\mathrm{C}=$ P. communis; $\mathrm{P}=$ P. pyrifolia. Hybrids are indicated by appropriate combinations.

${ }^{\mathrm{y}}$ In the "Marker Type" column, letters in parentheses represent the predicted maximum level of ethylene synthesis during fruit ripening. $\mathrm{H}=\mathrm{high}\left(>10 \mathrm{~nL} \cdot \mathrm{g}^{-1}\right.$ fresh weight $\left.\mathrm{h}^{-1}\right) ; \mathrm{M}=$ moderate $\left(0.5-10 \mathrm{~nL} \cdot \mathrm{g}^{-1}\right.$ fresh weight $\left.\mathrm{h}^{-1}\right) ; \mathrm{L}=$ low $\left(<0.5 \mathrm{~nL} \cdot \mathrm{g}^{-1}\right.$ fresh weight $\left.\mathrm{h}^{-1}\right)$. 
the CAPS marker (a 1.57-kb and $0.63-\mathrm{kb}$ band, respectively).

The following primers were used for classification of marker $\mathrm{B}$ of $P P A C S 2$, which is linked to moderate ethylene production: SYN2F (5'-GTCACAGAATCAA CGATTGA-3') and SYN2R (5'-AGTAGA ACGCGAAAACAAAT-3'). The PCR reaction was performed as described above, and amplified fragments were also digested with HindIII and separated on a $1.2 \%$ agarose gel in $1 \times$ TAE buffer. After staining with ethidium bromide, gels were observed and photographed under ultraviolet light. Identification of marker B was examined by the presence (Fig. 1) or absence of the CAPS marker (a $0.83-\mathrm{kb}$ and $0.35-\mathrm{kb}$ band, respectively) (Itai et al., 2003b). After analysis of both markers, cultivars were classified into one of the four RFLP types (AB, Ab, aB, or ab).

\section{Results and Discussion}

In the present study, a total of 152 cultivars was used to predict maximum ethylene production in Asian pears by CAPS analysis of ACC synthase genes. Based on the presence or absence of polymorphic fragments, cultivars were classified into one of four groups: $\mathrm{AB}, \mathrm{Ab}, \mathrm{aB}$ or $\mathrm{ab}$. The correlations between groups and rates of ethylene production were identified previously (Itai et al., 1999, 2003b); groups AB and Ab showed high ethylene production, group $\mathrm{aB}$ showed moderate production, and ab showed low ethylene production. Marker types of a total of 152 cultivars, including 35 cultivars previously identified by RFLP analysis (Itai et al., 1999), are listed in Table 1. Overall, $15,23,53$, and 61 cultivars were shown to belong to groups $\mathrm{AB}, \mathrm{Ab}, \mathrm{aB}$, and $\mathrm{ab}$, respectively. A large number of group $a b$ and $a B$ cultivars were listed, but only a small number of $\mathrm{AB}$ and $\mathrm{Ab}$ cultivars. These data suggest that there has been a decrease in high ethylene producers (marker type of $\mathrm{AB}$ or $\mathrm{Ab}$ ) over the years because of their low storage ability. In line with this, recently bred cultivars such as 'Akemizu', 'Kosui', 'Shinsui', 'Shugyoku', 'Yasato', 'Wakahikari', 'Akiakari', 'Akibae', 'Akizuki', 'Ohshuu', 'Shurei', and 'Zuishu' have been classified as aB or ab; no newly bred cultivars belong to groups $\mathrm{AB}$ or $\mathrm{Ab}$. On the other hand, the high ethylene producers, which belong to groups $\mathrm{AB}$ or $\mathrm{Ab}$, include a large number of older cultivars such as 'Awayuki', 'Okuroku', 'Rokugatsu', and 'Sotoorihime' (Kajiura and Sato, 1990). Despite the development of refrigeration systems, our data indicate that cultivation of cultivars with a short shelf life is still problematic, with cultivars having a long storage potential being preferred.

The ab cultivars lack expression of PPACS1 and PPACS2 during fruit ripening and the trait for low ethylene production is recessive (Itai et al., 2002, 2003b). Hybridization between ab cultivars results in seedlings with low ethylene during fruit ripening. If the breeding objective is to increase storage ability, ab cultivars are a good genetic resource for production of new cultivars with a long shelf life. Most Asian pear cultivars are susceptible to scab (Venturia nasicola), which, along with black spot, is one of the most prevalent diseases affecting $P$. pyrifolia. Of the examined cultivars, 'Hongli' and 'Mili', low ethylene producers classified as $\mathrm{ab}$, are resistant to scab (Abe and Kotobuki, 1998), and accordingly, have received much attention. Hybridization between 'Osanijisseiki' (a self-compatible mutant of 'Nijisseiki') and 'Hongli' are now in progress with the aim of breeding new self-compatible cultivars resistant to black spot and scab, and with a long shelf life. To date, four molecular markers including ours have been associated with self-incompatibility, black spot (Alternaria alternata Japanese pear pathotype), scab, and fruit ethylene production (Banno et al., 1999; Sassa et al., 1997; Takasaki et al., 2004; Terakami et al., 2006). Thus, these markers can be used for markerassisted selection of these four traits.

In conclusion, measurement of maximum ethylene production is a complex task because determining the accurate time of fruit ripening in Asian pears is often problematic. As a result, underestimation often occurs when using fruits harvested earlier than the optimum date. Our CAPS analysis is a rapid and accurate method for predicting relative levels of ethylene production and gaining posthandling information. Furthermore, information on marker types enables the identification of cultivars for hybridization aimed at enhancing shelf life in Asian pear breeding.

\section{Literature Cited}

Abe, K. and K. Kotobuki. 1998. Inheritance of high resistance to Venturia nashicola Tanaka et Yamamoto in Japanese pear (Pyrus pyrifolia Nakai) and Chinese pear (P. ussuriensis maxim.). J. Jpn. Soc. Hort. Sci. 67:677-680.
Banno, K., H. Ishikawa, Y. Hamauzu, and H. Tabira. 1999. Identification of a RAPD marker linked to the susceptible gene of black spot disease in Japanese pear. J. Jpn. Soc. Hort. Sci. 68:476-481.

Dellaporta, S.L., J. Wood, and J.B. Hicks. 1983. A plant DNA minipreparation: Version II. Plant Mol. Biol. Rep. 1:19-21.

Downs, C.G., C.J. Brady, J. Campbell, and W.B. McGlasson. 1991. Normal ripening cultivars of Pyrus serotina are either climacteric or nonclimacteric. Scientia Hort. 48:213-221.

Itai, A., T. Kawata, K. Tanabe, F. Tamura, M. Uchiyama, M. Tomomitsu, and N. Shiraiwa. 1999. Identification of 1-aminocyclopropane-1carboxylic acid synthase genes controlling the ethylene level of ripening fruit in Japanese pear (Pyrus pyrifolia Nakai). Mol. Gen. Genet. 262:42-49.

Itai, A., T. Kotaki, K. Tanabe, F. Tamura, D. Kawaguchi, and M. Fukuda. 2003a. Rapid identification of 1-aminocyclopropane-1-carboxylate (ACC) synthase genotypes in cultivars of Japanese pear (Pyrus pyrifolia Nakai) using CAPS markers. Theor. Appl. Genet. 106:1266-1272.

Itai, A., K. Tanabe, and F. Tamura. 2002. Mechanism of ethylene production during fruit ripening in Asian pears. Acta Hort. 587:497-504.

Itai, A., K. Tanabe, F. Tamura, and M. Tomomitsu. 2003b. Cloning and characterization of a cDNA encoding 1-aminocyclopropane-1-carboxylate (ACC) synthase (PPACS3) from ripening fruit of Japanese pear (Pyrus pyrifolia Nakai). J. Jpn. Soc. Hort. Sci. 72:99-106.

Jackson, J.E. 2003. Biology of apples and pears. Cambridge University Press, Cambridge, UK.

Kajiura, I. and Y. Sato. 1990. Recent progress in Japanese pear (Pyrus pyrifolia Nakai) breeding and descriptions of cultivars based on literature review. Bull. Fruit Tree Res. Stn. 1:97-329.

Kitamura, T., T. Iwata, T. Fukushima, Y. Furukawa, and T. Ishiguro. 1981. Studies on the maturation-physiology and storage of fruits and vegetables. II. Respiration and ethylene production in reference to species and cultivars of pear fruit. J. Jpn. Soc. Hort. Sci. 49:608-616.

Sassa, H., H. Hirano, T. Nishio, and T. Koba. 1997. Style-specific self-compatible mutation caused by deletion of the S-RNase gene in Japanese pear (Pyrus serotina). Plant J. 12:223-227.

Takasaki, T., K. Okada, C. Castillo, Y. Moriya, T. Saito, Y. Sawamura, N. Norioka, S. Norioka, and T. Nakanishi. 2004. Sequence of the S-9RNase cDNA and PCR-RFLP system for discriminating S-1- to S-9-Allele in Japanese pear. Euphytica 135:157-167.

Terakami, S., M. Shoda, Y. Adachi, T. Gonai, M. Kasumi, Y. Sawamura, H. Iketani, K. Kotobuki, A. Patocchi, C. Gessler, T. Hayashi, and T. Yamamoto. 2006. Genetic mapping of the pear scab resistance gene Vnk of Japanese pear cultivar Kinchaku. Theor. Appl. Genet. 113:743-752. 